Vol. 5, No. 2, 2019

УДК 327:331.556.4(450)

https://doi.org/10.23939/shv2019.02.029

\title{
MIGRANT WORKERS AS THE SUBJECTS OF UKRAINE'S CIVIL DIPLOMACY (ON EXAMPLE OF UKRAINIAN-ITALIAN RELATIONS)
}

\author{
Lesia Dorosh \\ Lviv Polytechnic National University \\ Researcher ID R-1453-2017 \\ Author ID: 57192267003 \\ lesia.o.dorosh@lpnu.ua \\ Sofiia Kobyletska \\ Lviv Polytechnic National University \\ ORCID: 0000-0003-0884-3216 \\ sofiia_pirianyk@ukr.net
}

(стаття надійшла до редколегї-20.09.2019 р., прийнята до друку - 20.10.2019 р.)

(С Дорош Л., Кобилеиька С., 2019

The problems of the treatment of labour migrants as subjects of civil diplomacy of Ukraine and their role in the establishment of the country image and the development of effective and mutually beneficial foreign relations of Ukraine and Italy have been analyzed. It has been emphasized on the social activity of labour migrants from Ukraine in protecting their rights and freedoms in Italy, as well as promoting the image of Ukraine, countering informational propaganda against our state. It has been noted that the involvement of individuals and their organizations in civil diplomacy is generally beneficial for the state because its citizens embody a certain national, cultural, and social identity. It has been asserted that if Ukraine will not protect its labour migrants in the host country, relations with the host country will deteriorate at least, and, it will be a deterioration of its foreign policy image in the international arena at the maximum. The activity of individuals and civil associations of Ukrainians in Italy, the role of the Greek-Catholic Church, the Ukrainian media as forms of the public and political activity of Ukrainians in Italy have been analyzed. It has been noted that, unlike propaganda, civil diplomacy, that is based on mutual trust between people, which is achieved through positive cooperation, rational thinking and feelings, can be considered as an important attribute of the soft power of Ukraine. It is argued that about the necessity of formulation of the foreign policy strategy by using the forms and mechanisms of public and civil diplomacy which demonstrates its effectiveness, including the use of the potential of labour migrants from Ukraine in promoting a positive foreign policy image of Ukraine.

Key words: civil diplomacy, state foreign policy, labour migration, Italy, Ukraine.

\section{ТРУДОВІ МІГРАНТИ ЯК СУБ'ЄКТИ ГРОМАДЯНСЬКОЇ ДИПЛОМАТІЇ УКРАЇНИ (НА ПРИКЛАДІ УКРАЇНСЬКО-ІТАЛІЙСЬКИХ ВІДНОСИН)}

\author{
Леся Дорош \\ Національний університет «Львівська політехніка» \\ Researcher ID R-1453-2017 \\ Author ID: 57192267003 \\ lesia.o.dorosh@lpnu.ua \\ Софія Кобилецька \\ Національний університет «Львівська політехніка» \\ ORCID: 0000-0003-0884-3216 \\ sofiia_pirianyk@ukr.net
}

\footnotetext{
Проаналізовано проблему виокремлення трудових мігрантів як суб’сктів громадської дипломатії України та їх ролі у становленні іміджу країни та розвитку ефективних та взаємовигідних зовнішньополітичних відносин України та Італії. Наголошено на громадській активності трудових мігрантів з України у ході захисту їх прав та
} 
свобод у Італії, а також просуванні іміджу України, протидії інформаційній пропаганді проти нашої держави. Відзначено, що залучення приватних осіб та їх організацій до громадянської дипломатії є, зазвичай, вигідним для держави, оскільки ії громадяни втілюють певну національну, культурну, соціальну ідентичність. Зазначено, що у випадку, коли Україна не захищатиме своїх заробітчан у країні перебування, можливе погіршення стосунків із країною перебування як мінімум, а як максимум - погіршення ії зовнішньополітичного іміджу на міжнародній арені. Проаналізовано активність окремих осіб та громадських об'сднань українців в Італії, роль грекокатолицької церкви, українських ЗМІ як форм громадсько-політичної діяльності українців в Італії. Зазначено, що на відміну від пропаганди, громадянська дипломатія, що побудована на взаємній довірі між людьми, яка досягається через позитивний досвід співпраці, раціональне мислення та відчуття, може вважатись важливим атрибутом м'якої сили України. Стверджується про необхідність формування стратегії зовнішньополітичної діяльності із використанням форм та механізмів громадської дипломатії, застосування якої демонструє ії ефективність, зокрема i 3 використанням потенціалу трудових мігрантів у поширенні позитивного зовнішньополітичного іміджу України.

Ключові слова: громадська дипломатія, зовнішня політика держави, трудова міграція, Італія, Украӥна

Ukrainian society and political elites are facing significant challenges and difficulties today which are associated with the transformation of the political system of Ukraine under the pressure of internal and external hybrid threats. First of all, it refers to the internal resistance to the aggressor in the military, political, legal, economic, cultural and informational, spiritual spheres. However, the active positioning of Ukraine in the international arena, diplomatic counteraction do not take the last place in the struggle against modern hybrid threats. It is not only about the use of the forms of classic diplomacy but also the full use of mechanisms and tools of citizen diplomacy. However, direct contacts with the public of other countries (leaders of opinions and average citizens) are especially important in the reporting of the truthful information about the situation in Ukraine. Citizen diplomacy in the context of the implementation of the soft and smart foreign policy strategy means the strengthening the role of non-governmental actors, increasing the openness and transparency of activities, increasing the value of mutual trust and cooperation [Сухорольська 2015: 36]. It can become an effective tool in modern hybrid confrontations of Ukraine.

The individuals and legal entities (students and teachers, businessmen, scientists, culture and art figures, labour migrants and others) [Сухорольська 2015: 24], non-governmental organizations, movements and institutions etc., whose activities are aimed at improving international relations, mutual understanding, cooperation and friendship among peoples, can be the subjects of citizen diplomacy [Медведева 2007: 71]. There are those who argue that the involvement of individuals and civil organizations to citizen diplomacy is generally beneficial to the state, because its citizens embody a certain national, cultural, and social identity. In this context, considering the urgent need to promote the positive image of our country in the international arena and to overcome its stereotyped, deliberately distorted image, it is necessary to involve a numerous Ukrainian diaspora, including the labour migrants, as a subject of the citizen diplomacy. They may have been involved in diplomatic activity in their own or common human interests. Thus, it will be a combination of own and foreign audiences when discussing domestic political and international issues; it will be possible to achieve an understanding of ideas and ideals of the Ukrainian people, its institutions and culture, as well as national goals and policies [Gilboa 2008: 57].

Such research is relevant because, in many countries, the relationship with the diaspora has become the basis of foreign policy and the Ukrainian government should provide support and development for the Ukrainian diaspora in Italy, which is an important factor for the foreign relations between the countries. The main problem of Ukrainians in Italy is the illegal status of migrants, which significantly complicates their stay in this country. To ensure their rights and preserve their culture and values in a certain way, Ukrainians have begun to unite in the civil organization, create Ukrainianlanguage media, Ukrainian websites and groups in social networks. In this way, they have engaged in the realization of citizen diplomacy of Ukraine.

The article aims to determine the advantages and prospects of involving the citizen diplomacy mechanisms in the foreign policy strategy of Ukraine, based on the analysis of the forms of the public and political activity of the Ukrainian diaspora (mainly labour migrants) in Italy.

The theoretical framework of the study is the works where the issues of citizen diplomacy as a form of state foreign policy are analyzed [Медведева 2007; Сухорольська 2015; Gilboa 2008; Melissen 2011; Signitzer, Coombs 1992]. Furthermore, the issue of external labour migration (in our case to Italy) has become the issue under scrutiny of the present study [Гаврилишин 2014]. The current literature on the problems and prospects of involving citizen diplomacy mechanisms to represent Ukraine and to protect its citizens through the prism of factors of labour migration abounds with examples of official statistical data 
[Державна служба статистики України: Офіційний вебсайт 2019].

Informational materials (including information from social networks, which virtually includes all associations, media, public activists, who are affiliated with Ukrainian communities in Italy) have become a prominent information source for this research. For example, on the official website of the Embassy of Ukraine in Italy and on the Embassy's page in the social network Facebook current news in Ukraine, information on cultural events and the rights of Ukrainians in Italy are highlighted [Посольство України в Італії 2019, Посольство України в Італії: Офіційний сайт 2019]. Activities of religious societies, non-governmental organizations, associations of migrant workers and their publishing, informational, cultural and educational activities are also described in detail on the Official website of the Ukrainian GreekCatholic Church (UGCC) in Italy [Українська грекокатолицька церква в Італії 2019]. There is an opportunity to learn about the activities of some of the Ukrainian organizations in Italy and their significance for Ukrainians in Italy on their websites. To understand the role of the Ukrainian community in Italy in establishing international relations, the journalistic sources were used, but they relate to some (including sensational) cases [Про нас 2015].

The analysis of the source base confirms that there is insufficient research on the aspects of the application of citizen diplomacy (including the analysis of the possibility of involving of Ukrainian labour migration as its subject). Therefore, further research in this area may include the study of the peculiarities of various forms of citizen diplomacy that can be applied in intergovernmental (Ukraine and Italy) and interpersonal relations.

At the end of the XX - beginning of the XXI century, a large number of Ukrainians left their homes in search of better earnings and life. According to the State Statistics Service of Ukraine, most of the Ukrainian citizens choose the following countries: Russian Federation, Italy, Poland, Spain, Portugal, Czech Republic, Greece. Italy is the third country (after Poland and the Russian Federation), which accepts the largest number of migrant workers from Ukraine [Державна служба статистики України: Офіційний вебсайт 2019]. The State Statistics Service of Ukraine has published that officially 146,700 Ukrainians have left for work to Italy in 2015-2017. This is the amount of the legal migrants, who mostly enjoy the same social rights as Italian workers. We can not say the same about illegal labour migrants, whose number is significantly larger than the group of legal workers.
The consensus view seems to be that the problems of life establishing of such a large number of Ukrainians in Italy require very active public involvement. The activity of Ukrainians results in the fact that in the majority of cases, the problems are solved by the Italian side.

Today, the Ukrainian community in Italy needs support from the official state authorities of Ukraine, there are problems with representing the interests of the Ukrainian diaspora in the Italian public authorities. It can be explained by the fact that these institutions do not have Ukrainian representatives who would have a direct impact on the Italian authorities and could initiate or influence the proposals put forward by the Ukrainian community. There are only a few cases when among the many Ukrainians who have permanent employment in the social sector there were those who were fortunate enough to hold positions at the state and public institutions in Italy. For foreigners to participate in the political life of Italy, the state authorities decided to create, at the mayors of largest cities, the position of «additional counsellors from foreign communities», who can attend city council meetings and express their opinion. For example, Tetyana Kuzyk was the Ukrainian, who has worked in City Hall of Rome for 5 years and fulfilled the duties of the Commissioner of the Mayor of Rome for Immigrants for six months. This is a great achievement for Ukrainians in Italy. In this position, T. Kuzyk was able to raise funds from the City Hall of Rome for free training seminars for immigrants who have just arrived in the country. The building where the cultural events of the Ukrainian community are taking place today is also a credit to T.Kuzyk. Besides establishing the Ukrainian secondary schools in Rome, a Ukrainian was able to open such schools in Brescia, Naples, Pescara, Venice-Mestre, Caserta, and Padova [Маріанна Сореневич 2016]. For a brief period, exlabour migrant Tetyana Kuzyk was able to assist the Ukrainian community in Italy. Therefore, we consider it important the Ukrainians be in the government of Italy. Hope relies on children who were born and live in Italy and have Italian citizenship but are Ukrainians by birth. However, so far, there is no significant influence of foreign Ukrainian associations on the proper policy of the Italian government concerning Ukraine.

An important step in positioning of the Ukrainian community as political power is the creation of the Public Council at the Embassy of Ukraine in Italy in 2014 by the representatives of the Ukrainian associations. The Council includes only officially registered associations in Italy. The council's activities are aimed at providing pension support for migrant workers, advocacy in the Italian media, opening schools 
and working with young people, and strengthening the volunteer movement which would provide humanitarian assistance to Ukraine. This is a particular body that lobbies for the interests of Ukrainians in Italy [Українці Італії об'єдналися в раду при посольстві 2014].

The Ukrainian Greek-Catholic Church in Italy also takes a special place in the social, political and cultural life of Ukrainian labour migrants [Українська греко-католицька церква в Італії 2019]. For example, the resolution of the First Forum of Ukrainians in Italy, which took place on the initiative of the UGCC in 2003, appealed to the Ukrainian public and to the Government of Ukraine to sign an intergovernmental agreement between Ukraine and Italy on the protection of the rights of Ukrainian labour migrants, the regulation of customs duties at the borders, the opening of full-fledged consulates and the establishment of the Ukrainian schools. Also, the Christian Society of Ukrainians in Italy was established at this Forum [Лебіщак, Городецький 2003: 14].

Another factor to consider is the activities of the European Cultural Association «Italy-Ukraine Maidan», whose president is Italian Fabio Prevedello. The European Cultural Association was established with the beginning of protests on the Maidan in Ukraine and from that time has provided food and clothing to those who protested. Hence, the main purpose of the association is to provide humanitarian aid to those Ukrainian regions where it is most needed. The President of the Association in 2015 was awarded the Order of Merit of the 3rd Degree by the President of Ukraine. The Association brings together non-indifferent Italians who bring humanitarian aid and medical equipment to those in need (orphanages, hospitals, civilians) [Асоціація «ІталіяУкраїна Майдан» привезла для лікарень Сходу України чергові 20 тонн гуманітарної допомоги 2016]. With the assistance of the Embassy of Ukraine in Rome and the Consulate General in Milan, various events and demonstrations in support of Ukraine are organized, where humanitarian aid is have been collected. Besides, the organization not only supports but also organizes Ukrainian cultural events in Italy [Наталія Кудрик 2016].

The mass media also have the importance of establishing friendly relations between Ukraine and Italy and the proper protection of the rights of the Ukrainian diaspora in this country. We speak about Ukrainianlanguage mass media, which would inform and facilitate the process of integrating of Ukrainian workers into the Italian society and contributed to the formation and integration of diaspora representatives abroad [Гаедіо Дель С. 2013]. Today, there are a lot of such mass media, which are mostly based on their own accord, with the support of the associations of Ukrainian communities and local authorities. We are talking about printed and online publications, television, radio, and social networks. Ukrainian-language media in Italy focus on legalization, legal education, payment, the life of the Ukrainian diaspora and visits to Ukrainian churches. Some of the media have a well-established relationship with the Ministry of Internal Affairs of Italy. There were publications on legal regulations of foreigners' living in Italy, prepared by experts of the Ministry and translated into Ukrainian. It is worth mentioning such an issue as recognizing the Ukrainian driver's license in Italy. Thus, the editorial board of «Ukrainian newspaper» together with Ukrainian carriers collected signatures for an open letter to the President, the Ministry of Foreign Affairs, the Embassy of Ukraine in Italy, with the call to accelerate the signing of an agreement with Italy on the recognition of the Ukrainian driving licenses [Про нас 2015].

The Internet and print media mostly inform about cultural events of Ukrainians in Italy. It should be noted the special place of such information, which helps to unite Ukrainians, to be informed about all events and activities, because only by uniting they can represent themselves to the Italians by overcoming the distortion of the information by the Russian media. Cultural events take place in the Ukrainian language, and eventually in Italian. The Italian language is used because there is a better opportunity to convey true information about what is happening in and around Ukraine.

Separately, one should focus on the activity of the Ukrainian diaspora in Italy in social networks, where hundreds of groups and pages aim to share information, ideas, views, experiences and integrate Ukrainians into the community (both virtually and really). Of course, many of these groups are «fake» and created by proRussian people, and, therefore, one must carefully look at the posts that are posted, as well as at the number of members in the groups. On the other hand, it is possible to disclose the «fake» information, to intensificate of constructive discussions on various issues of domestic and international development through such informal communication.

To sum up, when investigating the forms of the public and political activity of Ukrainians in Italy, it should be noted the long stay in Italy, the mass legalization, the need to protect their rights, the large number of well-educated labour migrants, the participation of the UGCC in the lives of labour migrants. All these factors have become a driving force for the formation of associations of Ukrainian workers. This is a great achievement when Ukrainians hold positions in the Italian government at various levels, have 
the opportunity to communicate the proposals of Ukrainian citizens to Italian officials and politicians, and, therefore, support the newest Ukrainian diaspora in Italy and promote the foreign policy relations between the two countries.

All things considered, Ukrainian labour migrants can be considered as citizen diplomats of Ukraine, who, through their active position in the host country, will contribute to the implementation of the key objectives of such diplomacy: the implementation of information exchange, the alleviation of negative clichés and prejudices, the formation of a favorable attitude to the foreign policy of the country, its social and political structure, as well as the strengthening of the positive image of Ukraine [Benno H. Signitzer, Timothy Coombs 1992, 139]. Through mechanisms of citizen diplomacy, it will be deepening of the mutual understanding of our cultures, improving relationships and behaviour, building and managing relationships, and influencing views and mobilizing actions to advance Ukraine's interests and values [Jan Melissen 2011, 2]. However, it should be understood that to achieve the objectives, the coordination of work and joint projects of Ukrainians and their associations in Italy is necessary. It should be understood that, unlike propaganda, citizen diplomacy, that is based on mutual trust between people, which is achieved through positive cooperation, rational thinking and feelings, can be considered as an important attribute of the soft power of Ukraine. That is why these Ukrainians, who, in dealing with foreigners, defend the Ukrainian vision of international problems, can be called true citizen diplomats of Ukraine.

\section{ЛІТЕРАТУРА}

Асоціація «Італія-Україна Майдан» привезла для лікарень Сходу України чергові 20 тонн гуманітарної допомоги, 23 квітня 2016 р. (2016). Новинарня. Отримано 3 https://novynarnia.com/2016/04/23/asotsiatsiya-italiyaukrayina-maydan-privezla-dlya-likaren-shodu-ukrayinichergovi-20-tonn-gumdopomogi/.

Гаврилишин, П. (2014). Українська трудова імміграція в Італії (1991-2011рр.). Брустурів: Дискурсус.

Державна служба статистики України: Офіційний вебсайт. (2019). Отримано з http://www.ukrstat.gov.ua/

Кудрик, Н. (2016). Волонтерам в Україні бракує фахової підготовки - італійський активіст. Рadio «Свобода», 16 травня 2016 р. Отримано 3 https://www.radiosvoboda.org/a/27736894.html

Лебіщак, В., Городецький, О. (2003). І скликав Форум українців... До Світла, 5, 4-14.

Медведева, Т. (2007). Основные методы и формы гражданской дипломатии в современном политическом процессе. Власть, 4, 71-74.

Посольство України в Італії. (2019). Отримано 3 https://www.facebook.com/ukr.embassy.italy/.
Посольство України в Італії: Офіційний сайт. (2019). Отримано з http://italy.mfa.gov.ua/ua

Про нас. (2015). Українська газета, 8 вересня 2015 р. Отримано 3 https://www.gazetaukrainska.com/ uncategorized/ 2015-09-08-12-40-13/

Сальваторе, Г. (2013). Італізми в українськомовних ЗМІ Італії. Стиль $i$ текст, 14, 66-73. Отримано 3 http://nbuv.gov.ua/UJRN/sit_2013_14_9

Сореневич, М. (2016). Українка балотується депутатом мерії міста Рим. Украӥнська газета. IT. Отримано $3 \mathrm{https} / /$ www.gazetaukrainska.com/українськаіталія/громада/українка-балотується-депутатом-мері/

Сухорольська, I. (2016). Громадська дипломатія як чинник демократизації політичної системи України: дис. ... канд. політ. наук. Львів: [б.в.].

Українська греко-католицька церква в Італії. (2019). Отримано 3 http://www.chiesaucraina.it/index.php/uk/

Українці Італії об'єдналися в раду при посольстві. (2014). Радіо «Свобода», 7 листопада 2014 р. Отримано 3 https://www.radiosvoboda.org/a/26679551.html

Gilboa, E. (2008). Searching for a Theory of Public Diplomacy. Annals of the American Academy of Political and Social Science, Vol. 616 [Public Diplomacy in a Changing World], No. 1, 55-77.

Melissen, J. (2011). Beyond the New Public Diplomacy. Clingendael Paper, No. 3. Отримано 3 http://www.clingendael.nl/sites/default/files/

20111014_cdsp_paper_jmelissen.pdf

Signitzer, B. H., Coombs, T. (1992). Public Relations and Public Diplomacy: Conceptual Covergences. Public Relations Review, Vol. 18, No. 2, 137-147.

\section{REFERENCES}

About Us. (2015). The Ukrainian newspaper.IT, September 8, 2015. [In Ukrainian]. Retrieved from https:/www.gazetaukrainska.com/uncategorized/2015-09-0812-40-13/

Embassy of Ukraine in Italy. (2019). [In Ukrainian]. Retrieved from https://www.facebook.com/ukr.embassy.italy/

Embassy of Ukraine in Italy: Official Website. (2019).

[In Ukrainian]. Retrieved from http://italy.mfa.gov.ua/ua

Gilboa, E. (2008). Searching for a Theory of Public

Diplomacy. Annals of the American Academy of Political and Social Science, Vol. 616 [Public Diplomacy in a Changing World], No. 1, 55-77.

Havrylyshyn, P.(2014). Ukrainian labor immigration in Italy (1991-2011). [In Ukrainian]. Brusturiv: Dyskursus.

«Italy-Ukraine Maidan» Association brought 20 tons of humanitarian aid to hospitals of Eastern Ukraine (2016). [In Ukrainian]. Novynarnia. Retrieved from https://novynarnia.com/2016/04/23/asotsiatsiya-italiyaukrayina-maydan-privezla-dlya-likaren-shodu-ukrayinichergovi-20-tonn-gumdopomogi/

Kudryk, N. (2016). Ukrainian volunteers lack the professional training - the Italian activist. [In Ukrainian]. Radio Liberty, May 16, $2016 . \quad$ Retrieved from https://www.radiosvoboda.org/a/27736894.html

Lebishchak, V., Horodetskyi, O. (2003). And Forum called the Ukrainians... [In Ukrainian]. Towards the light, 5, 4-14. 
Medvedeva, T. (2007). The basic methods and forms of civil diplomacy in the modern political process. [In Ukrainian]. Power, 4, 71-74.

Melissen, J. (2011). Beyond the New Public Diplomacy. Clingendael Paper, No. 3. Отримано 3 http://www. clingendael.nl /sites/default/files/20111014_cdsp_paper_jmelissen.pdf

Salvatore, G. (2013). Italianisms in the Ukrainian Language Media of Italy. [In Ukrainian]. Style and Text, 14, 66-73. Retrieved from http://nbuv.gov.ua/UJRN/sit_2013_14_9

Signitzer, B. H., Coombs, T. (1992). Public Relations and Public Diplomacy: Conceptual Covergences. Public Relations Review, Vol. 18, No. 2, 137-147.

Sorenevych, M. (2016). The Ukrainian is running for a deputy of the City Hall of Rome. [In Ukrainian]. The Ukrainian newspaper, IT. Retrieved from https://www. gazetaukrainska.com/українська-італія/громада/українкабалотується-депутатом-мері/

State Statistics Service of Ukraine: Official Website. (2019). [In Ukrainian]. Retrieved from http://www. ukrstat.gov.ua/

Sukhorolska, I. (2016). Public diplomacy as a factor in the democratization of political system of Ukraine: Autoreferat of Dissertation, PhD. in Political Science. Lviv: [without Publisher]

Ukrainian Greek-Catholic Church in Italy. (2019). [In Ukrainian]. Retrieved from http://www.chiesaucraina.it/ index.php/uk/

Ukrainians in Italy join Council at the Embassy. (2014). [In Ukrainian]. Radio Liberty, November 7, 2014. Retrieved from https://www.radiosvoboda.org/a/26679551.html 